\title{
Irrigation Scheduling Impact Assessment MODel (ISIAMOD): A decision tool for irrigation scheduling
}

\author{
Henry. E. Igbadun \\ Department of Agricultural Engineering, Ahmadu Bello University, P.M.B. 1044, Zaria, Kaduna State, Nigeria \\ igbadun20@yahoo.com
}

\begin{abstract}
This paper presents a process-based simulation known as Irrigation Scheduling Impact Assessment MODel (ISIAMOD). It was developed to simulate crop growth \& yield, soil water balance and water management response indices to define the impact of irrigation scheduling decisions. ISIAMOD was calibrated and validated using data from field experiments on the irrigated maize crop conducted in an irrigation scheme located in south western Tanzania. The model adequately simulates crop biomass yield, grain yield, seasonal evapotranspiration and average soil moisture content in the crop effective rooting depth. Some unique features of this model make it a major improvement over the existing crop-soil simulation models.
\end{abstract}

Keywords: Simulation model, Irrigation scheduling, Water management, Crop water productivity, ISIAMOD

Introduction

Application of computer-based simulation models as tools for providing support for decision-making in agricultural research has increased tremendously in the last three decades. In the field of irrigation, dynamic process-oriented simulation models are being used to evaluate irrigation-scheduling practices in different parts of the developed and developing countries. Some of the fairly popular models include, IRSIS (Raes et al., 1986), SWATRE (Belman et al., 1983) CROPWAT (Smith, 1992), CERES-Maize (Jones \& Kiniry, 1986), EPIC (Williams et al., 1989), CropSyst (Stockle \& Nelson, 1996), SWAP (van Dam et al., 1997), and APSIM (McCown et al., 1996).

Despite the fact that quite a number of crop-soilirrigation simulation models already exist, there are always reasons to modify existing models or develop new ones to perform the desired task. One primary reason is that the choice of model to solve a problem largely depends on the nature and location of the problem as well as the desired results. Unfortunately, no single model can claim universal applicability. Moreover, readily available models may not possess the features or capability to give a desired output or solving a problem in a desired way. Therefore, the need to modify an existing model or develop a new one to address the task at hand becomes necessary.

This objective of this paper is to present a processbased crop growth cum irrigation scheduling model developed to generate Water Management Response Indices (WMRI) which is used to assess the level of impact of irrigation scheduling decisions on crops and its environment. The paper specifically presents the features of this model, its calibration and validation for irrigated maize crop.

Materials and methods

Model description

The Irrigation Scheduling Impact Assessment Model (ISIAMOD) is a process-based model created to simulate crop growth process, soil water balance of a cropped field, and water management response indices (WMRI).
ISIAMOD runs on daily time-step, from crop planting date to crop physiological maturity date. The input data required in the model include weather, soil, crop, and irrigation scheduling decisions. The minimum weather data required are daily maximum and minimum ambient temperatures for the duration of crop growth. Other weather parameters which are optional include wind speed, maximum and minimum relative humidity, sunshine hour or solar radiation.

The soil input data include volumetric soil moisture content at field capacity and at wilting point, initial soil moisture contents, bulk density, and the percentage of sand in the soil texture. The soil profile is to be divided into a minimum of four and a maximum of ten layers, and each layer is divided into a number of compartments, such that the total number of compartments of the entire soil profile can be up to sixty. The division of the soil profile into layers and compartments is to facilitate numerical computation of the soil water flux.

The infiltration and distribution of water within the soil profile is based on the "tipping bucket" method (Campbell \& Daiz, 1988; Zhang et al., 2004). Each compartment is assumed to be filled with water to field capacity after irrigation or heavy rainfall, and then passes on excess water to the compartment below. Any water which passes beyond the bottom layer of the profile depth is assumed lost to deep percolation. No upward movement of water in the profile is allowed.

ISIAMOD assumes irrigation and rainfall as the only sources of water input to the cropped field. Through the process of evaporation, water is removed from the uppermost soil layer of the cropped field. Through the process of transpiration water is removed from the crop root zone depth which increases down the soil profile as the crop rooting depth. Soil water is assumed held in an unsaturated state within the crop root zone for crop use. Soil moisture beyond the potential at which water can be held in the plant root zone is drained out of the zone via the process of deep percolation. The model assumes a one-dimension vertical movement of water in the soil profile. It assumes that the soil has a high hydraulic 
conductivity, with no drainage impediment. Therefore, there is no temporary storage of water in excess of field capacity beyond two days. It also assumes a soil with a deep water table, and consequently no significant contribution from groundwater to the plant root zone.

The crop input data include maximum rooting depth, maximum leaf area index, potential (non-water limited) harvest index, radiation use efficiency (RUE), radiation extinction coefficient, and peak crop water use coefficient $\left(\mathrm{K}_{\mathrm{c}}\right)$. Others include crop base and optimum temperatures; leaf area index shape factors; water-limited harvest index adjustment factors; crop planting, emergence, and physiological maturity dates; days from planting for the start of each of the four crop growth stages, and fraction of the crop growth duration at which leaf area index started to decline. The model divides the crop growth stages into four: crop establishment, vegetative, flowering and maturity (which include seed formation through to maturity).

A unique feature of the model which makes it an improvement on existing model is water management response indices (WMRI) module which generates the water accounting indices, crop productivity indices and the seasonal relative deficit/losses indices used to define the level of impact of an irrigation scheduling decision on the crop and the environment. In addition, the reference evapotranspiration module has eight options of weather data combination for calculating reference evapotranspiration (ETo) based on the Penman-Monteith and Hargreaves methods as detailed by Allen et al. (1998). This makes the model versatile and flexible to accommodate limited weather input data. The options include: (1) Maximum and minimum temperature, wind speed, maximum and minimum relative humidity, and solar radiation; (2) Maximum and minimum temperature, wind speed, maximum and minimum relative humidity, and sunshine hours; (3) Maximum and minimum temperature, wind speed, maximum relative humidity, and solar radiation; (4) Maximum and minimum temperature, wind speed, maximum relative humidity, and sunshine hours; (5) Maximum and minimum temperature, wind speed, and solar radiation; (6) Maximum and minimum temperature, wind speed, and sunshine hours; (7) Maximum and minimum temperature, and wind speed; and (8) Maximum and minimum temperature only. When the only weather parameters available are maximum and minimum temperature, reference evapotranspiration will be calculated using the Hargreaves' method (Hargreaves \& Samani, 1985).

The irrigation scheduling module is also equipped with five options of irrigation timing criteria and three options of water application depth (WAD) from which the user can select. The irrigation timing criteria include: (1) User's specified dates of irrigation and depths of water to be applied; (2) Fixed irrigation interval throughout the crop growing season; (3) Fixed irrigation interval per growth stage; (4) Fixed maximum allowable depletion (MAD)
Vol. 5 No. 8 (August 2012) ISSN: 0974-6846 throughout the crop growing season; (5) Fixed MAD per growth stage. The water application option include: (1) Depth of water equals the amount of water used by the crop at user's defined water application efficiency; (2) Fixed depth of water throughout the crop growing season; (3) Fixed water application depth per growth stage. ISIAMOD allows a combination of any of the timing criteria with any water application depth options. However, this rule does not apply when the user chooses to use the first option of irrigation timing criteria in which the user specifies the dates and depth of water to be applied.

The model simulation output include crop growth response like leaf area index, crop rooting depth, crop biomass, final harvest index and grain yield; soil water balance components such as daily soil moisture content, evaporation, transpiration, runoff, deep percolation, and rainfall interception. The crop yields and water balance components outputs are further processed by the model to generate the water management response indices which include the water accounting, crop water productivity, and seasonal relative deficit/losses indices. It is these indices that are used to assess the impact of the irrigation schedule. ISIAMOD program was written in FORTRAN language and compiled using Microsoft FORTRAN PowerStation version 1.0F. The executable file runs on command prompt of Windows XP. Fig. 1 shows the schematic diagram of the model.

The modules of ISIAMOD

The modules of ISIAMOD consist of the following: Biomass yield module

The biomass yield module of ISIAMOD is given as:

$$
\triangle B P_{i}=0.01 * R U E * P A R *\left(B_{G L F}\right)^{2}
$$

Where $\triangle \mathrm{BPi}$ is daily increase in biomass (t/ha); RUE is crop parameter for converting energy to biomass, referred to as radiation use efficiency $(\mathrm{g} / \mathrm{MJ})$; PAR is photosynthetic active radiation $\left(\mathrm{MJ} / \mathrm{m}^{2}\right)$ (Sharpley \& Williams, 1990), $B_{G L F}$ is the biomass growth limiting factor.

The biomass growth limiting factors considered are temperature and water stress. The temperature-limiting factor ( $\left.T_{G L F}\right)$ is expressed as (Stockle \& Nelson, 1996):

$$
\begin{aligned}
& T_{G L F}=1.0 \quad \text { if } T_{a v g}>T_{o p t} ; \\
& T_{G L F}=0.0 \text { if } T_{a v g}<T_{\text {base }} \text {; and } \\
& T_{G L F}=\frac{T_{a v g}-T_{\text {base }}}{T_{\text {opt }}-T_{\text {base }}} \quad \text { otherwise }
\end{aligned}
$$

where, $T_{\text {opt }}$ is crop parameter optimal temperature for the crop growth; $T_{\text {base }}$ is base temperature at which there is no crop growth; and $\mathrm{T}_{\text {avg }}$ is daily average temperature. 
The water stress growth-limiting factor $\left(\mathrm{WSF}_{\mathrm{GLF}}\right)$ is expressed as the ratio of actual transpiration $(\mathrm{Ta})$ to the potential transpiration $\left(\mathrm{T}_{\mathrm{p}}\right) ; \quad W S F_{G L F}=\frac{T_{a}}{T_{p}}$

\section{Harvestable yield module}

The harvestable yield is obtained as the product of the biomass yield at maturity, crop harvest index $(\mathrm{HI})$, and adjusted water stress factors during flowering and grain filling. The expression is given as (Sharpley \& Williams, 1990):

$$
C H Y=B P_{c u m} * H I_{p o t} *\left[\left(W S F_{G L F}\right)_{f l}\right]_{f f l} *\left[\left(W S F_{G L F}\right)_{g f}\right] \mathrm{kgf}
$$

Where, $\mathrm{HI}_{\text {pot }}$ is potential (non water-stressed) harvest index, $\left(\mathrm{WSF}_{\mathrm{GLF}}\right)_{\mathrm{fl}}$ is water stress factor at flowering ( $\left.\mathrm{fl}\right)$ growth stage; $\left(\mathrm{WSF}_{\mathrm{GLF}}\right)_{\mathrm{gf}}$ is water stress factor at grain filling (gf) growth stage; agf and afl are harvest index adjustment parameters for water stress during flowering and grain yield, respectively.

\section{Leaf area index}

The daily increment in leaf area index during the canopy development stage is given as:

$$
\Delta L A I_{i}=\left(P L A I_{i}-P L A I_{i-1}\right) *\left(W S F_{G L F}\right)^{0.5}
$$

Where, and the PLAli is potential (without water stress) leaf area index on day I; PLAli-1 is the potential leaf area index the previous day. The other parameter has been previously defined.

The potential leaf area index was defined as:

$$
P L A I_{i}=\frac{L A I_{\max }}{\left\{1+G S F^{*} E X P\left(-b^{*} D_{i}\right)\right\}}
$$

Where, $\mathrm{LAI}_{\max }$ is maximum leaf area index, which is a crop parameter, GSF is growth shape factor and $b$ is a coefficient.

The fraction of the crop growth duration was given as:

$$
D_{i}=\frac{i-i_{p l d}}{i_{m t d}-i_{p l d}}
$$

Where, ' $i$ ' is day of the year from planting; $i_{\text {pld }}$ is the day of the year of planting, and $i_{m t d}$ is the day of the year of crop maturity.

The leaf area index from the start of decline to end of the growing season was expressed as:

$$
L A I_{i}=D L A I_{i} *\left(W S F_{G L F}\right)^{0.5}
$$

and

$$
D L A I i=L A I o *\left\{\frac{\left(1.01-D_{i}\right)}{\left(1.01-D_{0}\right)}\right\}^{\beta}
$$

Where, $D L A l_{i}$ is declining leaf area index on day ' $i$ ' under moisture stress-free condition. LAlo is leaf area index on the day (Do) when leaf area index decline began, and beta is the leaf area index decline adjustment factor. Other parameters are as previously defined.

\section{Potential evapotranspiration partitioning module}

The $\mathrm{ET}_{0}$ is first converted to crop maximum evapotranspiration $\left(E T_{c}\right)$ using a factor $(\mathrm{Kc})$, expressed as:

$E T_{c}=K_{c} * E T_{o}$

Kc factor is defined as (Stockle \& Nelson, 1996):

$K c=1+\left(K c^{\prime}-1\right) * \frac{L A I}{3}$

if $K c^{\prime}>1$ and $L A I<3$

$K c=K c^{\prime} \quad$ Otherwise

if $=K c^{\prime}<1$ then $K c=K c^{\prime}$

Where, $\mathrm{Kc}^{\prime}$ is peak crop coefficient, LAl is leaf area index with a maximum value of three for the reference crop (Stockle \& Nelson, 1996).

The maximum evapotranspiration is partitioned to potential evaporation and potential transpiration using the fractional solar radiation interception factor. The partitions are expressed as:

$E_{p}=(1-F I) * E T_{c}$

$T_{p}=E T_{c}-E_{p}$

Where, $E_{p}$ is potential evaporation from the cropped soil surface; $T_{p}$ is potential transpiration; $\mathrm{Fl}$ is fractional solar radiation interception factor, and $\mathrm{ET}_{\mathrm{c}}$ is the crop maximum evapotranspiration.

Solar radiation interception module

The fractional radiation interception factor was expressed as (Yang et al., 2004):

$F I=\left[1-\operatorname{EXP}\left(-R E X F^{*} L A I\right)\right]$

Where, $\mathrm{FI}$ is fractional radiation interception coefficient by the crop canopy; REXF is radiation extinction coefficient, and $\mathrm{LAl}$ is leaf area index.

Actual evaporation module

The actual evaporation rate is expressed as:

$E_{a}=E_{p}$ if $\theta \geq \theta_{f c}$

$E_{a}=E_{p} * \frac{\theta-\theta_{p w p}}{\theta_{f c}-\theta_{p w p}} \quad$ Otherwise

When the soil moisture content of the evaporation layer reaches the wilting point, the rate of evaporation becomes (Campbell \& Daiz, 1988):

$$
E_{a}=E_{p} *\left[\frac{\theta-\theta_{a d w c}}{\theta-\theta_{a d w c}}\right]^{2}
$$

where, $E_{a}$ is actual evaporation from the cropped soil surface; $E_{p}$ is potential evaporation from the cropped surface; $\theta$ is moisture content of the soil; $\theta_{\mathrm{fc}}$ is moisture content of the soil at field capacity, $\theta_{\mathrm{pwp}}$ is moisture content of the soil at wilting point, and $\theta_{\text {adwc }}$ is air-dry moisture content, given as one-third of moisture content wilting point (Stockle \& Nelson, 1996). 


\section{Crop actual transpiration module}

The actual transpiration (root water uptake) is expressed as (Plauborg et al., 1996):

$T_{a}=T_{p} \quad$ if $\theta \geq \theta_{f c}$;

$T_{a}=0.0$ if $\theta \leq \theta_{p w p} \quad$ and

$T_{a}=T_{p} *\left[1-\left(\frac{\theta-\theta_{p w p}}{\theta-\theta_{p w p}}\right)^{\frac{C T}{T_{p}}}\right]$ Otherwise (22)

Where, $T a$ is actual transpiration; $T_{p}$ is potential transpiration, and CT is an empirical soil dependent constant of a range of 10 to $12 \mathrm{~mm} /$ day (Plauborg et al., 1996). The other terms are as previously defined.

\section{Rooting depth module}

The daily increment in rooting depth as influenced by the root-growth limiting factor is expressed as:

$$
\triangle R D_{i}=\left(P R D_{i}-P R D_{i-1}\right) *\left(R D_{G L F}\right)^{0.5}
$$

Where $\triangle R D_{i}$ is daily increase in rooting depth; $P R D_{i}$ is potential (unrestricted and non water limited) root depth, and $\mathrm{RD}_{\mathrm{GLF}}$ is dominant factor which limits rooting depth on a given day i. (This factor could be water stress or soil strength or both (Sharpley \& Williams, 1990)). The soil stress factor is as defined by Sharpley \& Williams (1990).

The potential (unrestricted and non water limited) root depth is given as (Campbell \& Daiz, 1988):

$$
P R D_{i}=\frac{R D_{\max }}{1+442 * \operatorname{EXP}\left(-8.5^{*} D_{i}\right)}
$$

\section{Root density module}

The root density module is given as (Campbell \& Daiz, 1988):

$$
\begin{gathered}
F R_{l}=\Delta Z_{l} * \frac{2 *\left(R D-Z_{l}\right.}{R D^{2}} \\
\text { if } Z_{l} \leq R D \\
F R_{i}=\left[\frac{R D-\left(Z_{l}+\Delta Z_{l}\right)}{R D}\right]^{2} \\
\quad \text { if } Z_{l}-\Delta Z_{l}<R D<Z_{l}
\end{gathered}
$$

Where, $F R_{1}$ is fractional root density in layer $\mathrm{l}$; $R D$ is rooting depth, and $\Delta Z_{1}$ is incremental depth in the soil profile.

The depth of water removed from a soil layer by transpiration is a function of the fractional root density in the layer I expressed as (Campbell \& Daiz, 1988):

$$
T_{a l} * T_{a} * F R_{l}
$$

Where $T_{a}$ is total amount of water removed by transpiration, $T_{a l}$ is amount removed from soil layer $l$.
Vol. 5 No. 8 (August 2012)

ISSN: 0974- 6846

\section{Water response management indices module}

This module consists of the water accounting, crop water productivity and seasonal relative deficit indices.

The water accounting indices are defined as:

Transpiration efficiency $=F_{T a}=\frac{T_{a}}{W S}$

Evaporation index $=F_{E a}=\frac{E_{a}}{W S}$

Evapotranspiration efficiency $=F_{E T a}=\frac{E T_{a}}{W S}$

Runoff Index $=F_{R f}=\frac{R f}{W S}$

Percolation index $=F_{D p}=\frac{D P}{W S}$

where, WS is the amount of water supplied either through irrigation, rainfall or both; $\mathrm{Ta}$ is transpiration, $\mathrm{Ea}$ is evaporation, ETa is evapotranspiration; Rf is runoff and DP is deep percolation.

The crop water productivity indices are defined as:

Productivity of water supplied

$=C W P_{W S}=\frac{\text { Crop yield }}{W S}$

Productivity of water used in evapotranspiration =

$C W P_{E T a}=\frac{\text { Crop yield }}{\text { SET }}$

Productivity of water used in transpiration =

$$
C W P_{T a}=\frac{\text { Crop yield }}{T_{a}}
$$

The seasonal relative deficit/losses indices relate the yield and crop water use outputs of the scheduling strategy to the potential output (non-water limiting) expected in the local area. These include:

Seasonal relative biomass yield loss

$S R L_{D M}=\left(1-\frac{D M_{a}}{D M_{p}}\right)$

Seasonal relative grain yield loss $S R L_{G Y}=\left(1-\frac{G Y_{a}}{G Y_{p}}\right)$

Seasonal relative ET deficit $S E T_{\text {Deficit }}=\left(1-\frac{S E T_{a}}{S E T_{c}}\right)$ 
Seasonal $\left.\begin{array}{r}\text { relative } \\ S T R_{\text {deficit }}=\left(1-\frac{S T R_{a}}{S T R_{p}}\right.\end{array}\right)$

transpiration

deficit Tanzanian Ministry of Agriculture Training Institute farms located in the Igurusi ya Zamani Traditional Irrigation Scheme (IZTIS) in Igurusi town, Mbeya Region, south western Tanzania, for the purpose of calibration and

Fig. 1. Schematic diagram of the ISIAMod with input and output information

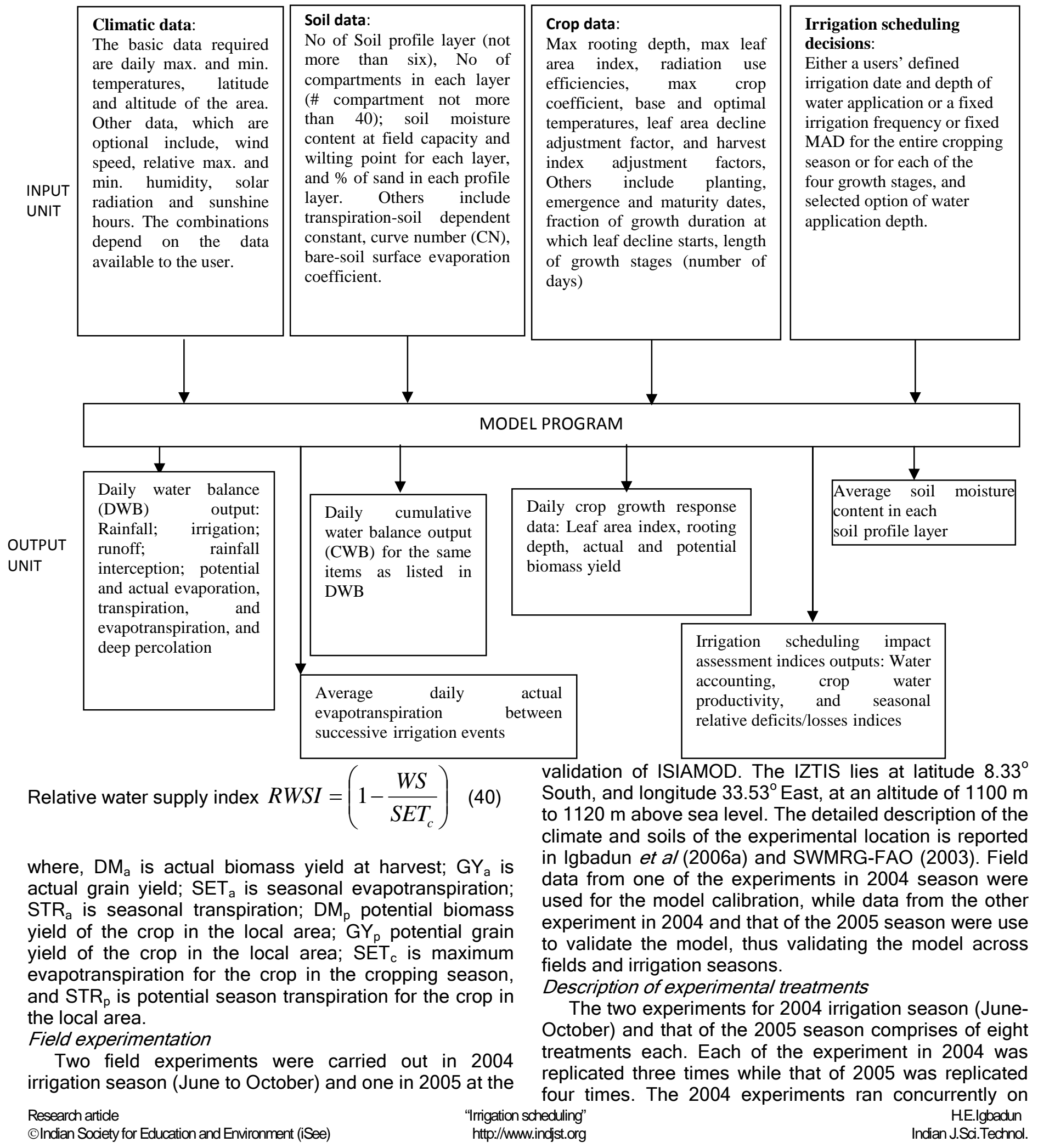


separate fields about $250 \mathrm{~m}$ apart. Planting was done on $24^{\text {th }}$ June, 2004. The experiment in the 2005 season was carried out on one of the fields used during the 2004 season. Planting was done on $6^{\text {th }}$ July 2005 . The experimental treatments for the three experiments in the

Table 1. Description of the experimental treatments

\begin{tabular}{|c|c|}
\hline Treatment No. & Description \\
\hline $1\left(\mathrm{TR}_{1111^{*}}\right)$ & $\begin{array}{l}\text { Irrigated weekly without skipping irrigation } \\
\text { at any crop growth stage. (Reference } \\
\text { treatment). }\end{array}$ \\
\hline $2\left(\mathrm{TR}_{1011}\right)$ & $\begin{array}{l}\text { Irrigation was skipped every other week at } \\
\text { vegetative stage only. Weekly irrigation } \\
\text { was observed at flowering and grain filling } \\
\text { growth stages. }\end{array}$ \\
\hline $3\left(\mathrm{TR}_{1101}\right)$ & $\begin{array}{l}\text { Irrigation was skipped every other week at } \\
\text { flowering stage only. Weekly irrigation was } \\
\text { observed at vegetative and grain filling } \\
\text { growth stage. }\end{array}$ \\
\hline $4\left(\mathrm{TR}_{1110}\right)$ & $\begin{array}{l}\text { Irrigation was skipped every other week at } \\
\text { grain filling stage only. Weekly irrigation } \\
\text { was observed at vegetative \& flowering } \\
\text { growth stages. }\end{array}$ \\
\hline $5\left(\mathrm{TR}_{1001}\right)$ & $\begin{array}{l}\text { Irrigation was skipped every other week at } \\
\text { vegetative and flowering stages. Weekly } \\
\text { irrigation was observed only at grain filling } \\
\text { growth stage. }\end{array}$ \\
\hline $6\left(\mathrm{TR}_{1010}\right)$ & $\begin{array}{l}\text { Irrigation was skipped every other week at } \\
\text { vegetative and grain filling stages. Weekly } \\
\text { irrigation was observed only at flowering } \\
\text { growth stage. }\end{array}$ \\
\hline $7\left(\mathrm{TR}_{1100}\right)$ & $\begin{array}{l}\text { Irrigation was skipped every other week at } \\
\text { flowering and grain filling stages. Weekly } \\
\text { irrigation was observed only at vegetative } \\
\text { growth stage. }\end{array}$ \\
\hline $8\left(\mathrm{TR}_{1000}\right)$ & $\begin{array}{l}\text { Irrigation was skipped every other week at } \\
\text { vegetative flowering and grain filling } \\
\text { stages. }\end{array}$ \\
\hline \multicolumn{2}{|c|}{$\begin{array}{c}\text { * The subscripts represent the growth stages: } 1=\text { weekly } \\
\text { irrigation at the growth stage and } 0=\text { irrigation was skipped } \\
\text { every other week at the stage. Vegetative growth stage = } \\
\text { 24-64 days after planting (DAP); flowering stage = 65-93 } \\
\text { DAP; grain filling to Maturity = 94-120 DAP. }\end{array}$} \\
\hline
\end{tabular}

two seasons were the same and their description is summarized in Table 1. The treatment variable was the frequency of irrigation, and the variations were created by skipping irrigation every other week at one or more growth stages of the crop. This treatment variation approach is similar to Pandey et al. (2000). The experimental treatment design, method of irrigation water application, and other agronomic practices have been reported in Igbadun et al. (2006b). Table 2 shows the irrigation schedule observed for the experiments.

\section{Data collection}

The data collected for the purpose of calibrating and validating the model include the soil moisture content from every treatment two days after irrigation and just before irrigation; final biomass yield, and the grain yield. The soil moisture contents were monitored using the Theta probe during the 2004 season and a Neutron probe during the 2005 season. The soil moisture contents were determined for soil profile depth of $100 \mathrm{~cm}$ at interval of 15 $\mathrm{cm}$ incremental depth. From the soil moisture content data, the weekly crop water use (evapotranspiration) for each treatment was computed using the soil moisture depletion expression (Michael, 1999).The final biomass and grain yields were obtained for each treatment by harvesting the above ground dry matter from the treatment plots and weighed. The maize cobs were then harvested, threshed, and weighed to obtain the grain weight. The grain moisture content at threshing was about $13 \%$.

\section{Running the model}

The input data used for running the model include weather, soil, crop and irrigation scheduling decisions. The weather data were obtained from the meteorological station in the Ministry of Agriculture Training Institute (MATI), Igurusi town, for the two seasons. The soil data were those of the experimental site. The irrigation scheduling decision input data (the timing of irrigation and amount of water applied) was in accordance with Table 2. The crop input data and other parameters are given in Table 3.

\section{Calibration procedure}

Calibration of model refers to quantifying parameters of the model using system observations and the

Table 2. Irrigation scheduling

\begin{tabular}{|c|c|c|c|c|c|c|c|c|c|c|c|c|c|c|c|c|c|c|c|}
\hline \multirow{2}{*}{$\begin{array}{c}\text { Growth } \\
\text { stage } \\
\text { Wk of } \\
\text { irrigation }\end{array}$} & \multicolumn{3}{|c|}{$\begin{array}{c}\text { Crop } \\
\text { establishment }\end{array}$} & \multicolumn{6}{|c|}{ Vegetative } & \multicolumn{4}{|c|}{ Flowering } & \multicolumn{4}{|c|}{ Grain filling } & \multirow{3}{*}{ NIE } & \multirow{3}{*}{$\begin{array}{c}\text { TW } \\
\text { A }\end{array}$} \\
\hline & $0^{*}$ & 1 & 2 & 3 & 4 & 5 & 6 & 7 & 8 & 9 & 10 & 11 & 12 & 13 & 14 & 15 & 16 & & \\
\hline $\begin{array}{c}\text { Treatment } \\
\text { label }\end{array}$ & \multicolumn{17}{|c|}{ Water application depth per irrigation (mm) } & & \\
\hline $1\left(\mathrm{TR}_{1111^{*}}\right)$ & 30 & 30 & 30 & 30 & 30 & 40 & 40 & 4 & 40 & 50 & 50 & 50 & 50 & 50 & 50 & 50 & 40 & 17 & 700 \\
\hline $2\left(\mathrm{TR}_{1011}\right)$ & 30 & 30 & 30 & 30 & $x$ & 40 & $x$ & 4 & $x$ & 50 & 50 & 50 & 50 & 50 & 50 & 50 & 40 & 14 & 590 \\
\hline $3\left(\mathrm{TR}_{1101}\right)$ & 30 & 30 & 30 & 30 & 30 & 40 & 40 & 4 & 40 & 50 & $\mathrm{X}$ & 50 & $\mathrm{X}$ & 50 & 50 & 50 & 40 & 15 & 600 \\
\hline $4\left(\mathrm{TR}_{1110}\right)$ & 30 & 30 & 30 & 30 & 30 & 40 & 40 & 4 & 40 & 50 & 50 & 50 & 50 & 50 & $x$ & 50 & $\mathrm{X}$ & 15 & 610 \\
\hline $5\left(\mathrm{TR}_{1001}\right)$ & 30 & 30 & 30 & 30 & $\mathrm{X}$ & 40 & $x$ & 4 & $\mathrm{X}$ & 50 & $x$ & 50 & $\mathrm{X}$ & 50 & 50 & 50 & 40 & 12 & 490 \\
\hline $6\left(\mathrm{TR}_{1010}\right)$ & 30 & 30 & 30 & 30 & $X$ & 40 & $\mathrm{X}$ & 4 & $X$ & 50 & 50 & 50 & 50 & 50 & $X$ & 50 & $X$ & 13 & 500 \\
\hline $7\left(\mathrm{TR}_{1100}\right)$ & 30 & 30 & 30 & 30 & 30 & 40 & 40 & 4 & 40 & 50 & $\mathrm{X}$ & 50 & $\mathrm{X}$ & 50 & $x$ & 50 & $\mathrm{X}$ & 13 & 510 \\
\hline $8\left(\mathrm{TR}_{1000}\right)$ & 30 & 30 & 30 & 30 & $\mathrm{X}$ & 40 & $x$ & 4 & $X$ & 50 & $x$ & 50 & $X$ & 50 & $X$ & 50 & $\mathrm{X}$ & 10 & 400 \\
\hline
\end{tabular}


Table 3. Crop and other input parameters for the model

\begin{tabular}{|c|c|}
\hline Parameters & Value \\
\hline Maximum rooting depth & $1.2 \mathrm{~m}$ \\
\hline Maximum harvest index & $0.34^{*}$ \\
\hline $\begin{array}{l}\text { Harvest index adjustment factor for the } \\
\text { flowering stage }\end{array}$ & $0.45^{\star \star}$ \\
\hline $\begin{array}{l}\text { Harvest index adjustment factor for the } \\
\text { maturity stage }\end{array}$ & $0.5^{* *}$ \\
\hline Radiation extinction coefficient & $0.55^{\star *}$ \\
\hline Maximum leaf area index & $0.35 \mathrm{~m}^{2} / \mathrm{m}^{2}$ \\
\hline RUE (establishment and vegetative stages) & $0.25 \mathrm{~g} / \mathrm{MJ}^{* *}$ \\
\hline RUE (flowering and maturity stages) & $0.23 \mathrm{~g} / \mathrm{MJ}^{* *}$ \\
\hline Base temperature & $8^{\circ} \mathrm{C}$ \\
\hline Optimal temperature & $24^{\circ} \mathrm{C}$ \\
\hline $\begin{array}{l}\text { Fraction of the growth duration at which } \\
\text { leaf area index starts to decline }\end{array}$ & $0.75^{*}$ \\
\hline $\begin{array}{l}\text { Days after planting at which establishment } \\
\text { growth stage starts }\end{array}$ & $0^{*}$ \\
\hline $\begin{array}{l}\text { Days after planting at which vegetative } \\
\text { growth stage starts }\end{array}$ & $23^{*}$ \\
\hline $\begin{array}{l}\text { Days after planting at which flowering } \\
\text { growth stage starts }\end{array}$ & $64^{*}$ \\
\hline $\begin{array}{l}\text { Days after planting at which maturity } \\
\text { growth stage starts }\end{array}$ & $93^{*}$ \\
\hline Peak crop water use $(\mathrm{kc})$ coefficient & 1.2 \\
\hline Soil dependent transpiration constant & $\begin{array}{l}0.018 \\
\mathrm{~m} / \text { day }^{* *}\end{array}$ \\
\hline Evaporation coefficient for bare soil & 1.05 \\
\hline Growth shape factor GSF & 1120 \\
\hline $\mathrm{b}=$ exponent in the LAl equation & -17.2 \\
\hline
\end{tabular}

simulation outputs (Boote \& Jones, 1988). Model calibration involves a systematic adjustment of the parameters of a model such that the model can describe more closely the system behavior for site-specific application. During the process, the structure of the model remain the same and only the model parameters are adjusted until some values are obtained which brings the model simulated outputs close to the real system data. These values obtained are usually retained as the values for those parameters of the model for that sitespecific application.

The calibration of ISIAMOD for the site-specific and test crop involved adjusting the base values of some input parameters of the model within a range while the model simulated outputs were compared with field-measured data from Field 1 (2004) The input parameters adjusted include the soil dependent transpiration factor, harvest index adjustment factors, leaf area index module coefficients, canopy radiation extinction factor, and radiation use efficiency. The model outputs during the calibration process that were compared with fieldmeasured data include biomass yield at harvest, grain yield, and seasonal evapotranspiration. The final values of the adjusted parameters at which the model simulated outputs had the highest correlation with the fieldmeasured data were adopted as input data for the model.

\section{Validation procedure}

Model validation is a process of comparing modelsimulated results to real system data not previously used in calibration or in any parameter estimation process. The purpose of validation is to determine if the model is sufficiently accurate for its application as defined by the objective (Boote \& Jones, 1988).

The simulated output variables of the ISIAMOD were validated by comparing model-simulated results with field-measured data from Field 2 in the 2004 and 2005 seasons' experiments. The comparison was made between the field measured and the simulated final biomass yield, grain yield, seasonal evapotranspiration and average soil moisture content of the soil profile. The statistical performance indicators used for the comparison were (Mahdian \& Gallichard, 1995; Panda et al., 2004):

$$
\begin{aligned}
& A E=\frac{1}{n} \sum_{i=1}^{n}\left(P_{i}-O_{i}\right) \\
& C V=100 * \frac{\left[\frac{1}{n} \sum_{i=1}^{n}\left(P_{i}-O_{i}\right)^{2}\right]^{0.5}}{O_{m}} \\
& R M S E=\left[\frac{1}{n} \sum_{i=1}^{n}\left(P_{i}-O_{i}\right)^{2}\right]^{0.5} \\
& E F=\frac{\left[\sum_{i=1}^{n}\left(O_{i}-O_{m}\right)^{2}-\sum_{i=1}^{n}\left(P_{i}-O_{i}\right)^{2}\right]}{\sum_{i=1}^{n}\left(O_{i}-O_{m}\right)^{2}} \\
& C R M=\frac{\sum_{i=1}^{n} O_{i}-\sum_{i=1}^{n} P_{i}}{\sum_{i=1}^{n} O_{i}}
\end{aligned}
$$

Where $A E$ is average error of bias, CV is coefficient of variation, RMSE is root mean square error, EF is modeling efficiency, CRM is coefficient of residual mass, $\mathrm{Pi}$ is simulated values; $\mathrm{O}_{i}$ is measured values; $\mathrm{O}_{m}$ is mean of measured values, and $\mathrm{n}$ is the number of the observations.

The average error of bias (AE) is a measure of bias between the simulated and measured data. The coefficient of variation (CV) is a measure of variability while the root mean square error (RMSE) is a measure of precision. The modeling efficiency (EF) also referred to as the coefficient of Nash-Sutcliffe (Mahdian \& Gallichard, $1995)$ is a measure of the degree of fit between simulated and measured data. It is similar to the coefficient of determination $\left(r^{2}\right)$. EF varies from negative infinity $(-\infty)$ for
Research article

CIndian Society for Education and Environment (iSee) 
total lack of fit to 1 for an exact fitting (Mahdian \& Gallichard, 1995). The coefficient of residual mass (CRM) is an indicator of the tendency of the model to either overor under- predict measured values. A positive value of CRM indicates a tendency of under-prediction, while a negative value indicates a tendency of over-prediction (Antonopoulos, 1997).

Results and discussion Calibration

Table 4. Biomass yield at harvest, grain yield and harvest index of Field 1 (2004 season)

\begin{tabular}{|c|c|c|c|}
\hline $\begin{array}{l}\text { Treatment } \\
\text { label }\end{array}$ & $\begin{array}{l}\text { Biomass yield at } \\
\text { harvest }(\mathrm{kg} / \mathrm{ha})\end{array}$ & $\begin{array}{l}\text { Grain yield } \\
(\mathrm{kg} / \mathrm{ha})\end{array}$ & $\mathrm{SET}(\mathrm{mm})$ \\
\hline $\mathrm{TR}_{1111}$ & 11939.2 & 3831.7 & 548.7 \\
\hline $\mathrm{TR}_{1011}$ & 10166.4 & 3265.0 & 494.1 \\
\hline $\mathrm{TR}_{1101}$ & 10108.0 & 2837.4 & 505.6 \\
\hline $\mathrm{TR}_{1110}$ & 10361.2 & 3007.1 & 496.1 \\
\hline $\mathrm{TR}_{1001}$ & 8672.8 & 2370.9 & 449.5 \\
\hline $\mathrm{TR}_{1010}$ & 9921.6 & 2755.6 & 452.9 \\
\hline $\mathrm{TR}_{1100}$ & 8532.0 & 2321.2 & 449.8 \\
\hline $\mathrm{TR}_{1000}$ & 7572.0 & 1709.5 & 395.9 \\
\hline
\end{tabular}

Table 4 shows the biomass yield at harvest, grain yield and seasonal evapotranspiration data of Field 1 (2004 season) used in the model calibration. Table 5 shows the statistical comparison of the model-simulated and field-measured data for the final calibration test. The coefficients of variation (CV) between the simulated and measured data were quite low and the measures of the goodness of fit indicated by the modelling efficiency (EF) and the coefficient of determination $\left(r^{2}\right)$ were very good. Based on the statistics, ISIAMOD was considered standardized for the maize crop in the study area.

Table 5. Statistics of the comparison between simulated and measured grain yield, biomass yield and harvest index

\begin{tabular}{|c|c|c|c|}
\hline $\begin{array}{l}\text { Statistical } \\
\text { performance } \\
\text { indices }\end{array}$ & Grain yield & Biomass yield & Seasonal ET \\
\hline AE & -105.5 & -125.4 & -14.4 \\
\hline RMSE & 151.3 & 426.5 & 15.7 \\
\hline CV (\%) & 5.48 & 4.42 & 3.32 \\
\hline EF & 0.94 & 0.89 & 0.87 \\
\hline CRM & 0.04 & 0.01 & 0.03 \\
\hline
\end{tabular}

Units for $A E$ and RMSE for grain and biomass yield are $\mathrm{kg} / \mathrm{ha}$, Units for AE and RMSE seasonal evapotranspiration Model validation

\section{Biomass and grain yield}

Table 7. Statistics of the comparison between simulated and field measured biomass yield at harvest and grain yield for the 2004 and 2005 season

\begin{tabular}{|c|c|c|c|c|}
\hline \multirow{2}{*}{$\begin{array}{c}\text { Statistical } \\
\text { performance } \\
\text { Indices }\end{array}$} & \multicolumn{2}{|c|}{2004 season } & \multicolumn{2}{c|}{2005 season } \\
\cline { 2 - 5 } & $\begin{array}{c}\text { Biomass } \\
\text { yield }\end{array}$ & $\begin{array}{c}\text { Grain } \\
\text { yield }\end{array}$ & $\begin{array}{c}\text { Biomass } \\
\text { yield }\end{array}$ & $\begin{array}{c}\text { Grain } \\
\text { yield }\end{array}$ \\
\hline AE $^{*}$ & 292.6 & 62.3 & 235.9 & 128.6 \\
\hline RMSE & 572.7 & 183.4 & 448.4 & 270.8 \\
\hline CV (\%) & 6.08 & 6.89 & 4.32 & 8.96 \\
\hline EF & 0.85 & 0.90 & 0.94 & 0.89 \\
\hline CRM & -0.03 & -0.02 & -0.02 & -0.04 \\
\hline
\end{tabular}

* Unit of AE and RMSE for biomass yield and grain yield is $\mathrm{kg} / \mathrm{ha}$.

Table 6 shows the simulated and field measured biomass yield at harvest and grain yield for 2004 (Field 2) and 2005 seasons. Table 7 shows the statistics of the comparison between simulated and measured biomass yield at harvest for the 2004 and 2005 seasons (columns $2 \& 4$ ). The CRM shows that the model has a tendency to either over-predict biomass yield at harvest by 2 to $3 \%$, and grain yield by 2 to $4 \%$. The modeling efficiencies (EF) were between 85 and $95 \%$. The close relationship between the simulated and measured data was considered as a good performance of the model ability to predict biomass and grain yields.

\section{Seasonal evapotranspiration}

Table 8. Simulated and measured seasonal evapotranspiration for the 2004 and 2005 seasons in $\mathrm{mm}$

\begin{tabular}{|c|c|c|c|c|}
\hline \multirow{2}{*}{ Treatment } & \multicolumn{2}{|c|}{ 2004 season } & \multicolumn{2}{c|}{ 2005 season } \\
\cline { 2 - 5 } & Simulated & Measured & Simulated & Measured \\
\hline $\mathrm{TR}_{1111}$ & 545.7 & 541.1 & 540.0 & 514.2 \\
\hline $\mathrm{TR}_{1011}$ & 501.1 & 486.9 & 497.7 & 491.2 \\
\hline $\mathrm{TR}_{1101}$ & 496.4 & 502.6 & 499.0 & 468.0 \\
\hline $\mathrm{TR}_{1110}$ & 501.9 & 504.6 & 516.4 & 488.6 \\
\hline $\mathrm{TR}_{1001}$ & 449.8 & 443.7 & 448.6 & 450.6 \\
\hline $\mathrm{TR}_{1010}$ & 460.6 & 446.9 & 474.4 & 441.1 \\
\hline $\mathrm{TR}_{1100}$ & 437.6 & 451.6 & 461.0 & 439.9 \\
\hline $\mathrm{TR}_{1000}$ & 394.3 & 385.5 & 410.3 & 398.9 \\
\hline
\end{tabular}

Table 8 shows the simulated and the field-measured seasonal evapotranspiration for the 2004 and 2005 seasons, and Table 9 shows the statistics of the comparison between the simulated and the measured data. There was a tendency of over the prediction of the season evapotranspiration by $1 \%$ in the 2004 season and $4 \%$ in the 2005 season as indicated by the CRM. The

\begin{tabular}{|c|c|c|c|c|c|c|c|c|}
\hline \multirow{3}{*}{ Treatment } & \multicolumn{4}{|c|}{2004 season } & \multicolumn{4}{|c|}{2005 season } \\
\hline & \multicolumn{2}{|c|}{$\begin{array}{c}\text { Biomass yield } \\
(\mathrm{kg} / \mathrm{ha})\end{array}$} & \multicolumn{2}{|c|}{ Grain yield (kg/ha) } & \multicolumn{2}{|c|}{ Biomass yield (kg/ha) } & \multicolumn{2}{|c|}{ Grain yield (kg/ha) } \\
\hline & Simulated & Measured & Simulated & Measured & Simulated & Measured & Simulated & Measured \\
\hline $\mathrm{TR}_{1111}$ & 12360.92 & 12128.22 & 3949.34 & 3776.19 & 13293.02 & 12672.68 & 4461.24 & 4349.206 \\
\hline $\mathrm{TR}_{1011}$ & 10559.59 & 9600.89 & 3345.53 & 3056.08 & 11572.7 & 11401.19 & 3830.52 & 3828.571 \\
\hline $\mathrm{TR}_{1101}$ & 10294.52 & 10215.11 & 2879.79 & 2770.37 & 10963.94 & 11673.73 & 3163.62 & 3257.143 \\
\hline $\mathrm{TR}_{1110}$ & 11024.74 & 10247.11 & 3057.94 & 2812.70 & 12446.87 & 12104.76 & 3890.6 & 3352.381 \\
\hline $\mathrm{TR}_{1001}$ & 8442.15 & 8252.44 & 2330.51 & 2249.74 & 8834.93 & 8575.16 & 2416.68 & 2476.19 \\
\hline $\mathrm{TR}_{1010}$ & 9374.37 & 8721.78 & 2595.85 & 2734.39 & 10814.12 & 10534.92 & 3345.29 & 2844.444 \\
\hline $\mathrm{TR}_{1100}$ & 8649.88 & 9386.67 & 2014.14 & 2252.86 & 9475.01 & 9026.43 & 2344.46 & 2431.746 \\
\hline $\mathrm{TR}_{1000}$ & 6965.4 & 6778.84 & 1614.73 & 1637.04 & 7442.87 & 6966.67 & 1741.43 & 1625.397 \\
\hline
\end{tabular}


coefficients to variation (CV) very quite low and the modeling efficiency were moderately high $(>0.50$ in most cases) which can be taken for good model performance. The performance of ISIAMOD in simulating seasonal evapotranspiration compares favourably with the several

Table 9. Statistics of the comparison between simulated and measured seasonal evapotranspiration for the 2004 and 2005 seasons

\begin{tabular}{|l|c|c|}
\hline $\begin{array}{l}\text { Statistical } \\
\text { indices }\end{array}$ & 2004 season & 2005 season \\
\hline AE $(\mathrm{mm})$ & 3.06 & 19.38 \\
\hline RMSE $(\mathrm{mm})$ & 9.76 & 22.74 \\
\hline CV $(\%)$ & 2.08 & 4.93 \\
\hline EF & 0.95 & 0.56 \\
\hline CRM & -0.01 & -0.04 \\
\hline
\end{tabular}

models reported in literature. For example, Cavero et al.

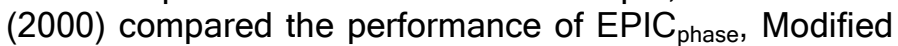
$\mathrm{EPIC}_{\text {phase }}$ and CROPWAT models and reported values of $1.51,-1.05$, and $37 \mathrm{~mm}$ as average error of bias (AE) between simulated and measured seasonal evapotranspiration for the three models, respectively. They also obtained RMSE of 39.8, 38.6 and $69.6 \mathrm{~mm}$ for EPIC $_{\text {phase, Modified EPIC }}$ phase and CROPWAT, respectively. Arora and Gajri (1996) also compared the performance of three simplified water balance models under maize in a semiarid subtropical environment and reported RMSE of 30,40 , and $30 \mathrm{~mm}$ for the Soil-PlantAtmosphere-Water (SPAW) model (Saxton, 1989), Water Balance Model (WBM) (Arora et al., 1987), and the modified WBM (Arora et al., 1987), respectively. The RMSE for ISIAMOD for the two seasons was 9.76 and $22.74 \mathrm{~mm}$, respectively.

Average soil moisture content of the effective root zone depth

Tables 10 shows the result of the statistics of the comparison between the measured and simulated volumetric soil moisture content of the effective root zone depth. The average error of bias $(A E)$ between the simulated and the measured data was $\pm 0.01 \mathrm{~m}^{3} / \mathrm{m}^{3}$ in both seasons. The RMSE was between 0.01 and 0.02 $\mathrm{m}^{3} / \mathrm{m}^{3}$. The coefficients of determination $\left(\mathrm{r}^{2}\right)$ were good $(>0.70)$ in most of the treatments in the 2004 season and were fair $(>0.50)$ in the 2005 season.

Table 10. Statistics of the comparison between simulated and measured volumetric soil moisture content of the effective root

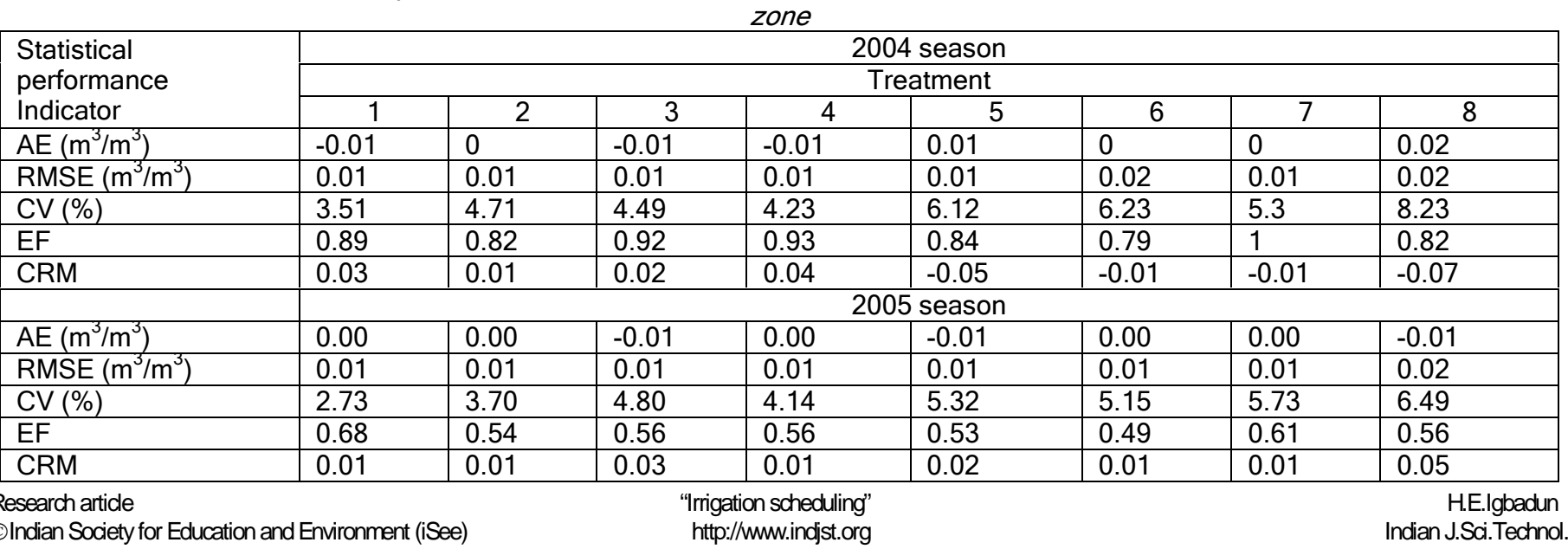

\section{Conclusion}

A simplified process-based simulation model known as Irrigation Scheduling Impact Assessment Model (ISIAMOD) was developed and validated. It was found to satisfactorily simulate grain yield of a maize crop and the soil water balance components of the cropped field. The model can be useful for on-the-desk assessing of the impact of irrigation scheduling protocols. Thus, the possible consequences of an irrigation scheduling protocol on the crop and its environment (the soil water balance) can be evaluated on the desk without going to the field. This model can be a strong tool in the hands of irrigation extension workers.

\section{Acknowledgment}

The work reported in this paper was part of the author's Ph.D. study in Sokoine University of Agriculture, Morogoro, Tanzania (2002-2006). The author wishes to use this opportunity to appreciate ANSTI-DAAD who sponsored the Ph.D. study.

\section{References}

1. Allen RG, Pereira LS, Raes D and Smith M (1998) Crop evapotranspiration: guideline for computing crop water requirements. FAO Irrigation \& Drainage paper. 56, pp: 300.

2. Antonopoulos VZ (1997) Simulation of soil moisture dynamics in irrigated cotton in semi-arid climates. Agr. Water Manage. 34, 233-246.

3. Arora VK and Gajri PR (1996) Performance of simplified water balance models under maize in a semiarid subtropical environment. Agr. Water Manage. 31, 57-64.

4. Arora VK, Prihar SS and Gajri PR (1987) Synthesis of a simplified water use simulation model for predicting wheat yield. Water Resour. Res. 23, 903-910.

5. Belman C, Wesseling JG and Feddes RA (1983) Simulation of the water balance of a cropped soil: SWATRE. J. Hydrol. 63, 271-286.

6. Boote KJ and Jones JW (1988) Application of, and limitation to, crop growth simulation models to fit crops and cropping systems to semi-arid environment. In: Drought Res. Priorities for the Dry Land Tropics. Bindinger FR \& Johansen C (ed.), ICRISAT, 
Patenchens, India. pp: 63-75.

7. Campbell GS and Diaz R (1988) Simplified soil-water balance models to predict crop transpiration. In: Drought Research Priorities for the Dryland Tropics, Bindinger FR \& Johansen C (Ed.), Parancheru, A.P. 502324, India: ICRISAT, pp.15-25.

8. Cavero J, Farre I, Debaeke P and Faci JM (2000) Simulation of maize yield under water stress with the EPICphase and CROPWAT models. Agronomy J. 92, 679-690.

9. Hargreaves GH and Samani ZA (1985) Reference crop evapotranspiration from temperature. Appl. Eng. Agr. 1(2), 96-99.

10. Igbadun HE, Mahoo HF, Tarimo AKPR and Salim BA (2006a) Performance of two temperature-based reference evapotranspiration models in the mkoji subcatchment in tanzania. Agr. Eng. Int. CIGR E J., Manuscript LW 05 008. Vol. VIII. April, 2006. ISSN Number 1682-1130.

11. Igbadun HE, Mahoo HF, Tarimo AKPR and Salim BA (2006b) Crop water productivity of an irrigated maize crop in Mkoji sub-catchment of the Great Ruaha River Basin, Tanzania. Agr. Water Manage. 85, 141-150.

12.Jones CA and Kiniry JR (1986) CERES-Maize: A simulation model of maize growth and development. Texas A \& M Univ. Press, College Station, Texas, pp: 150

13. Mahdian MH and Gallichand J (1995) Validation of the SUBSTOR model for simulating soil water content. Trans. Am. Soc. Agr. Eng (ASAE). 38, 513-520.

14. McCown RL, Hammer GL, Hargreaves JNG, Holzworth DP and Freebairn DN (1996) APSIM: A novel software system for model development, model testing, and simulation in agricultural research. Agr. Sys. 50, 255-271.

15. Michael AM (1999) Irrigation theory and practice. Reprint. Vikas Publ. House PVT Ltd. New Delhi. pp: 520.

16.Panda RK, Behera SK and Kashyap PS (2004) Effective management of irrigation water for maize under stress conditions. Agr. Water Manage. 66, 181203.

17.Pandey RK, Maranville JW and Admou A (2000) Deficit irrigation and nitrogen effects on maize in a sahelian environment I. Grain yield and yield components. Agr. Water Manage. 46, 1-13.

18.Plauborg $F$, Andersen MN, Heidmann $T$ and Olesen JE (1996) MARKVAND: an irrigation scheduling system for use under limited irrigation capacity in a temperate humid climate. In: Irrigation Scheduling from Theory to Practice. Water Reports 8. FAO-ICIDCIID, Rome. pp: 177-184.

19.Raes $D$, Lemmens $H$, van Aelst $P$, Vandebulcke $M$ and Smith M (1986) Irrigation scheduling information system (IRSIS). Ref. Manual No.3, Lab. Land Manage. K. U. Leuven, Belgium. pp: 119.
20.Saxton KE (1989) User manual for SPAW- A soil plant atmosphere water model. USDA-SEA-AR, Pullman, WA. pp: 90.

21.Sharpley A and Williams JR (1990) EPIC: Erosion, productivity impact calculator: 1. Model documentation. Technical Bull. 1768, USDA. pp: 145.

22.Smith M (1992) CROPWAT: A computer program for irrigation planning and management. FAO Irrigation \& Drainage Paper 46. FAO, Rome. pp: 89.

23. Stockle CO and Nelson R (1996) Cropping system simulation model. User's manual. Biol. Sys. Eng. Dept. Washington State Univ., Pullman WA 99164-6120, pp: 165.

24.SWMRG-FAO (2003) Comprehensive assessment of water resources of mkoji sub catchment, its current uses and productivity. FAO- Netherlands Partnership Programme, Water \& Food Security. IWRM for the Vulnerable Group. PR26935. pp: 50.

25.Van Dam, Huygen JC, Wesseling J, Feddes JG, Kabat RA, van Waslum P, Groenendjik PEV, PP and van Diepen CA (1997) Theory of SWAP version 2.0: Simulation of water flow and plant growth in the soilwater-atmosphere-plant environment. Technical Document 45. The Netherlands: Wageningen Agr. Univ. \& DLO Winand Staring Centre. pp: 90.

26. Williams JR, Jones CA, Kiniry JR and Spanel DA (1989) The EPIC crop growth model. Trans. Am. Soc. Agr. Eng. 32, 497-513.

27. Yang HS, Dobermann AJ, Lindquist L, Walker DT, Arkebauer TJ and Cassman KG (2004) Hybrid-maizea maize simulation model that combines two crop modelling approaches. Field Crops Res. 87, 131-154.

28.Zhang Y, Yu Q Liu C, Jiang J and Zhang X (2004) Estimation of winter wheat evapotranspiration under water stress with to semi-empirical approach. Agronomy J. 96, 159-168.
H.E.Igbadun Indian J.Sci.Technol. 